\title{
A vidéki térségek pozicionálási lehetősége a Csíki-medence településeinek példáján
}

\author{
SZÉKELY KINGA KATALIN ${ }^{1}$
}

\begin{abstract}
ABSZTRAKT
A gazdaságilag és társadalmilag is hátrányos helyzetben lévő rurális térségek, illetve azon periférikus települések számára, amelyek kimaradtak a fejlődés fó áramlatából, új esélyt, alternatívát jelenthetnek azok az irányzatok, amelyek az endogén erőforrások kiaknázását, a közösségfejlesztést, a társadalmi befogadást támogatják. Az új vidékfejlesztési szemlélet és az ehhez kapcsolódó térségfejlesztési megközelítések, mint a marketingorientált településfejlesztés, egy újfajta, piaci szemléletet feltételező, közösség-alapú irányzatra hívják fel a figyelmet, ahol sokkal jelentösebb szerepet kapnak a helyek, a helyi közösségek, megváltozik a helyi vezetöség funkciója és az endogén tényezők válnak a fó erőforrásokká. Középpontba kerül a kommunikációs tevékenység és a pozicionálási gyakorlat.
\end{abstract}

KULCSSZAVAK: településmarketing, rurális település, pozicionálás, fejlesztés

\section{ABSTRACT}

\section{Positioning Opportunities for Rural Areas Through the Example of Ciuc-Basin}

Those development approaches that support social inclusion, exploitation of endogenous resources and community development may be an alternative, and can offer new opportunities for the economically and socially disadvantaged rural areas and for peripheral settlements that have missed the mainstream of development. The new rural paradigm, and the related regional development approaches, such as marketing-oriented settlement development, point to a new community-based trend, where places, local communities get a more important role, the function of local management changes and endogenous factors become the main resource. The communication activity and positioning practice becomes more important.

KEYWORDS: place marketing, rural settlement, positioning, development

\footnotetext{
${ }^{1}$ Egyetemi adjunktus, Sapientia Erdélyi Magyar Tudományegyetem, Csíkszeredai Kar.
} 


\section{TEMATIKUS TANULMÁNYOK - Székelyföld - térség és társadalom}

\section{Bevezetés}

A térségmarketing szemlélete, alkalmazásának lehetőségei ma már egyre gyakrabban jelennek meg a térségfejlesztési és vidékfejlesztési szakmai diskurzusokban. Ez a törekvés tapasztalható a pozicionálással, a helyi identitással, a kommunikáció felértékelődésével kapcsolatos vizsgálatokban, a vidékkutatási és fejlesztéspolitikai megközelítésekben. Az új vidékfejlesztési paradigma több képviselője is (Van der Ploeg 2000, Woods 2007, Almstedt 2014) fontosnak tartja az egyes marketingeszközöknek a fejlesztési folyamatokban való alkalmazását, meglátásuk szerint a rurális térségeknek új narratívákra van szükségük, a helyi attrakciók újfajta megfogalmazására és a rurális településeknek az újrapozicionálására, illetve egyre fontosabb feladattá válik a vidékről, mint elmaradt térségről való kép megváltoztatása, az imázs javítása is (Nagy 2015).

A térségek és kistérségek vonzerejének növelése, a népszerűsítés, a kommunikációs tevékenységek hangsúlyozása egyre nagyobb hangsúlyt kapnak a székelyföldi térségben készült térségfejlesztési stratégiákban is. Jellemző azonban egyrészt az, hogy általában régiók és térségek marketingjéről szól a tematizálás. Amikor a településszintű marketingről esik szó, akkor rendszerint városi települések képezik az elemzés vagy a fejlesztéspolitikai javaslatok tárgyát. Rurális településekről jóval ritkábban van szó, de a településmarketing lehetőségeiről és ennek a térségmarketingre gyakorolt hatásáról sem születtek nagyobb számban elemzések, tanulmányok. ${ }^{2}$

Jelen tanulmány a településmarketing szemléletét, a helymárkázást és kommunikációs, pozicionálási gyakorlatot helyezi középpontba mint a rurális települések egy lehetséges fejlődési esélyét. Első lépésben arra vállalkozik, hogy ismertessen egy sajátos helyzetben, fejlődési szakaszban lévő térséget (Csíki-medence), valamint azokat a társadalmi, gazdasági előzményeket, jelenségeket, amelyek ennek a helyzetnek a kialakulásához vezettek. Majd ezt követően olyan szakmai megközelítéseket mutatok be, amelyek alátámasztják azt, hogy nem egyedi esetről van szó, hanem több rurális térség is hasonló fejlődési pályát jár(t) be mint az általam vizsgált Csíki-medence. Ezek a megközelítések, az endogén adottságok központba helyezésével megfogalmazzák azokat a szakmai lépéseket, irányokat, amelyek elmozdulási, továbblépési alternatívákat jelenthetnek ezen térségek számára. Az egyik ilyen irány a helyi márkázás, pozicionálási gyakorlat és településmarketing szemlélete.

Abból a feltételezésből kiindulva, hogy a vizsgált térség számára is ezek a megközelítések egy potenciális fejlődési lehetőséget kínálhatnak, elkészült egy komplex településszintű térséganalízis ${ }^{3}$, amelynek a kommunikációs tevékenységre vonatkozó részeredményeit ismertetem e tanulmány keretein belül.

\footnotetext{
${ }^{2}$ Kivétel: Horváth A. (2013): Turizmusfejlesztés Székelyföldön és Nagy B. (2013): A turisztikai helymarketing Székelyföldön - Az imázs- és márkahasználat tudományos megalapozása.

${ }^{3}$ Székely K. (2016): A Csíki-medence településeinek típusai és azok marketing szempontú vizsgálata. PhD dolgozat, Szent István Egyetem, Gödöllö.
} 


\section{TEMATIKUS TANULMÁNYOK - Székelyföld - térség és társadalom}

\section{Társadalomtörténeti előzmények}

A vizsgált térség alaposabb megismeréséhez szükségszerű számba vennünk a főbb társadalomtörténeti előzményeket is, hiszen ezek jelentősen befolyásolják a Csíki-medence jelenlegi fejlesztési gyakorlatát, a vele kapcsolatos attitűdöket, elgondolásokat, illetve a rurális települések működését. Ugyanakkor meg kell említenünk azokat a társadalmi, gazdasági tényezőket, amelyek a települések egymáshoz viszonyított fejlődésbeli különbségeit eredményezték.

A mai tevékenységeket és gondolkodásmódot alakító társadalomtörténeti öszszetevők sok esetben több évtizeddel korábbi társadalmi események termékei, s a tapasztalat azt mutatja, hogy ezek igen gyakran sokkal inkább rutinok, modellek, kulturális minták, mintsem tudatos, explicit módon megnyilvánuló konstrukciók. Ez a jelenség egy olyan, erőteljes lokális léptékű rehabilitációs folyamattal magyarázható, amely az 1989-es romániai politikai-gazdasági változást követően indult el. Ez a rehabilitációs folyamat jóval korábbi időszakok egész sor életvezetési, magatartási, tudásbeli összetevőjét elevenítette fel, korábbi formájában rehabilitálta vagy kisebb-nagyobb változtatásokkal újramodellezte (Biró et al. 2016). Ezzel a folyamattal részletesebben egy korábbi csoportos kutatás is foglakozott ${ }^{4}$.

A rehabilitációs folyamat egyéni/családi működési modelleket és közösségi jellegű szerveződési-működési mintákat hívott életre. Az etnikai összetevők fontos szerepet játszottak ennek a folyamatnak az elindításában, ugyanis lehetővé vált azoknak a közösségi jellegű jogfosztásoknak a helyreállítása, amelyeket az 1968-as területi újjászervezés okozott. Ugyanakkor megszűntek az olyan intézkedések, amelyek a 80-as években éleződtek ki, többek között az, hogy tilos volt a művelődési-kulturális élet szervezése rurális településeken, a települések nevét hivatalosan csak az állam nyelvén lehetett használni, a nem községközpont falvak intézményei megszűntek. Az 1989-es romániai változások után rurális térségben - s a Csíki-medencében kiemelten - nagy lendülettel, egyszerre több szinten indult be egyrészt a lokális identitás, másrészt a korábbi életforma rehabilitációja, s ehhez a máig tartó meghatározó szerepű folyamathoz a korábbi évtizedek tapasztalata és gyakorlata szolgáltatta a kivitelezési mintákat (Biró et al. 2016).

Az 1990-es évek az identitás rehabilitációs gyakorlat felpörgését hozták, ekkor stabilizálódott - elsősorban a kulturális élet és a szimbolikus térhasználat (Bodó 2000, 2011) előtérbe kerülése révén - a bottom-up típusú fejlesztési modellnek az úgynevezett befele forduló, máig domináns modellje.

Ezek a folyamatok kihatottak a térség egészére, befolyásolva a mai tevékenységeket, szemléleteket és attitűdöket, azonban a Csíki-medence településein a fejlődés

${ }^{4}$ Nemzeti identitás - lokális identitás - versenyképesség. Lokális identitások alakulása a Székelyföldi térségben: helyzetkép és fejlesztési lehetőségek MTA Határon Túli Magyar Tudományosságért Ösztöndíjprogram (2011) Kutatási jelentés. Kézirat, KAM - Regionális és Antropológiai Kutatások Központja. 


\section{TEMATIKUS TANULMÁNYOK - Székelyföld - térség és társadalom}

nem egyenlő arányban történt (történik), ezért is érdemes településszintű fejlesztésekről beszélnünk, nem csak regionális szintűről. A következőkben azokat a tényezőket ismertetem, amelyek meghatározták és befolyásolták a települések közti különbségek kialakulását.

A Csíki-medencére (Hargita megye, Románia) földrajzi, történelmi, kulturális, vallási szempontból is egységként tekinthetünk, de számos olyan társadalmi, gazdasági tényezőt tudunk felsorolni, melyek hatására fejlődésbeli különbségek alakultak ki a települések között. A térség települései az országos rendszer részei (jogi, adminisztratív, finanszírozási szempontból központilag vannak irányítva), viszont több tényezőnek (pl. erősödő lokális identitástudat, hagyományok, sajátos településirányítás, magyarországi kapcsolatok stb.) köszönhetően eltérő módon működnek, mint az ország többi települése, ez a kisebbségi helyzetből is adódik.

A kialakult helyzetre hatással voltak a társadalomtörténeti hagyományok (a lokalitás, a helyi identitásoknak az erőssége, a helyi intézményekhez, saját intézményekhez való viszonyulás), a településcentrikusság (falucentrikusság). Emellett egy másik meghatározó tényező az országos jogi adminisztratív keret (milyen helyi jogosítványok, intézmények vannak, létezhetnek a településeken). Szintén nagy hatása volt az 1989 utáni bejárt fejlődési pályának, ami településenként nagyon különböző. Ezt befolyásolta az, hogy kinek milyen kapcsolatai voltak - voltak-e parlamenti képviselői, támogatói -, miként használták ki az országos forráslehetőségeket (mire volt finanszírozás - itt fontos megjegyezni, hogy főleg infrastrukturális fejlesztési támogatások voltak).

A kisebbségi plusz támogatások is meghatározó tényezőként említhetők, ezeknek két típusa van, az egyik a megyei tanácsok támogatása - az ösztönzések, a szervezés, hálózati kezdeményezések - térségi erőforrásokból. A másik kisebbségi plusz a tudástranszfer, magyarországi kapcsolatok, képzések, a vidékfejlesztés ösztönzése, szakemberképzés, kistérségi kezdeményezések.

A táji, földrajzi adottságok, illetve azok társadalmi szervező hatása folyamatosan megjelenik a térséggel kapcsolatos történelmi és társadalomtörténeti (Vitos 1894/2002, Szádeczky 1927/1993, Endes 1937/1994, Venczel 1988, Hankó 1993, Ambrus 2012, Egyed 2013) elemzésekben. Ezek a vizsgálatok a Csíki-medencét, illetve annak társadalmát gyakorlatilag mindig egyedi, sajátos egységként említik vagy kezelik („Csíkszék”, ,„csík népe”, „Csíkország”, „,csíki székelyek” stb.).

A történelmi elemzésekben és kutatásokban megjelenő egyediség mai napig hatással van a térségi identitással (csíkiak) kapcsolatos ismeretekre és narratívákra.

Meg kell említeni ugyanakkor a közigazgatás szerepét is a jelen helyzet kialakulásában. A táji, földrajzi adottságok és a térség társadalomtörténete gyakran összekapcsolódott a közigazgatási szerveződési formákkal, ennek egyik sajátos formája a Székelyföldön belüli széki (Csíkszék) szerveződés (Endes 1937/1994, Hankó 1993).

A megyerendszer 1876-os kialakítását követően alakult meg Csík vármegye (amelyhez hozzákapcsolódik a Gyergyói-medence is), és erre az adminisztratív, tér- 


\section{TEMATIKUS TANULMÁNYOK - Székelyföld - térség és társadalom}

beli egységre vonatkozóan már alapos és sokrétű társadalmi, gazdasági elemzések is épültek (Vitos 1894/2003, Vámszer 1970/2000).

A két világháború közötti időszakban a Csíki-medence (Románia részeként) továbbra is egy periférikus térség maradt, nem történtek fejlesztések, a medence központja, Csíkszereda fejlődése is stagnált ebben az időszakban. Egyre inkább fokozódott az elköltözés Erdély nagyvárosaiba, illetve a fővárosba, Bukarestbe is. Főként a fiatalok költöztek el, ugyanis sokgyerekes székely családok számára (6-8 gyerek is született családonként) a családi földbirtok, erdőgazdálkodás nem jelentett megélhetést, ezért szakmát tanultak a nagyvárosokban (Biró - Laki 2001).

A második világháború utáni időszakban a térség Csík rajonként válik önálló területi egységgé, ez a státusz 1968-ban szűnik meg, amikor megalakul az új területi struktúra révén Hargita megye, amelyen belül a csíki térség Székelyudvarhely és Gyergyó vidéke mellett, a megyét alkotó három nagy tájegység egyikét képezi. ${ }^{5}$

A közigazgatási szerveződés éppen aktuális formáitól eltekintve is jellemző volt az, hogy a térség társadalma a központot képező város (Csíkszereda) és a medencében lévő rurális települések - város és vonzáskörzete - funkcionális egységeként múködött (adminisztratív ügyintézés, munkahely, tanulás, kereskedelem, kulturális és egyházi élet).

A társadalomtörténeti, közigazgatási és a társadalomszerveződési jellemzők mellett meg kell említenünk a mentális-identitásbeli összetevőket is, amelyek a csíki térségre sajátosan vonatkoznak, ezek egyrészt megjelennek a néprajzi leírásokban (népviselet, folklór, tárgyi néprajz, székely humor stb.), másrészt pedig a térségi identitással kapcsolatos hétköznapi narratívákban (milyen a „csíki ember”).

\section{Rurális térségek újrapozicionálása}

Amint a térségtörténeti áttekintésből is kiderült, az 1989 előtti időszak többféle módon korlátozta a Csíki-medence településeinek a fejlődését (települések összevonása, az egyéni tulajdonok megszüntetése, a fejlesztési erőforrásoknak a városokba való átcsoportosítása stb.). Az 1989 utáni változások sem kedveztek annak, hogy ezek a települések megerősödjenek és fel tudjanak zárkózni. Ez a jelenség azonban nem egyedi, a posztszocialista országok többsége küzd ezzel a problémával. Ahhoz, hogy jobban megértsük és értelmezni tudjuk a Csíki-medence társadalmi jelenségeit, több szakmai megközelítés is hasznos lehet. A következőkben ezek kerülnek rövid ismertetésre.

\footnotetext{
${ }^{5}$ Az adminisztratív szerveződéssel kapcsolatosan lásd Kánya 2003, Agyagási 2006, Demeter 2014.
} 


\section{TEMATIKUS TANULMÁNYOK - Székelyföld - térség és társadalom}

\section{A PERIFÉRIKUS, RURÁLIS TÉRSÉGEK ÉS TELEPÜLÉSEK FEJLŐDÉSI LEHETŐSÉGEI}

Beluszky (1993) az alföld periferizálása kapcsán megemlíti, hogy a falvak nem tudtak lépést tartani, nem tudtak élni a piacgazdaság lehetőségeivel, továbbra is jellemző a lakosságszám csökkenése, fennmaradtak a foglalkoztatottsági és megélhetési gondok.

Megállapítható, hogy főként az uniós csatlakozást követően elindult egy felzárkózási folyamat, de ha fejlődtek is ezek a települések, a városokhoz képest sokkal kisebb mértékben, mint ahogyan azt G. Fekete (2008) is említi, néhány éve lehet, hogy az önmagához képest pozitív irányba elmozduló, a helyi szükségleteket kielégítő folyamatokat fejlődésként, a jólét növekedéseként észlelték a helyi lakosok, azonban ma már a globalizációnak, az uniformizálódásnak köszönhetően ez nem így van. A lakosság elégedettsége egyre inkább attól függ, hogy milyen mértékben csökken a másoktól való lemaradás.

A téma szempontjából fontos említést tenni a perifériákról, illetve a gazdaságilag és társadalmilag is hátrányos helyzetben lévő rurális településekről, ugyanis a vizsgált térség ebbe a kategóriába sorolható. Perifériáknak nevezi G. Fekete (2008) azokat a térségeket, amelyek kimaradnak a fejlődés fó áramlatából, és csak alárendelt szerepben tudnak ehhez csatlakozni. Szerinte a jelenlegi perifériák alkalmatlannak bizonyultak a modernizációba való bekapcsolódáshoz, mert nem rendelkeznek azokkal az értékekkel, amelyek az ipari társadalomban fejlődést hoztak volna számukra. Ezen térségek számára jelenthetnek új esélyt, alternatívát azok az irányzatok, amelyek környezeti fenntarthatóságot, társadalmi befogadást, az egyénre szabott szomszédsági gazdaságot támogatják (Laville et al. 2005).

A rurális térségek helyzetének elemzésével, illetve a változás lehetőségével foglalkozó szakirodalmi anyagok (Van der Ploeg et al. 2000, Woods 2005, 2007, Almstedt et al. 2014) egyértelműen hangsúlyozzák azt, hogy a rurális térségeknek a pozitív irányú változása, fejlődése - ami alatt ők a globális kihívásoknak való megfelelést értik - alapvetően a rurális település gazdaságának az átalakulásához kell kapcsolódjon. Felhívják a figyelmet egy másik nagyon fontos tényezőre, amitől szintén nem lehet eltekinteni, ez a komplex értelemben vett gazdasági változás együtt kell járjon a potenciális fogyasztók megszólításával (turisták, új lakosok - városból kiköltözők, gazdasági szereplők, befektetők, szervezetek stb.). Az idézett szerzők szerint a rurális térségeknek új narratívákra van szükségük. A helyi attrakciók újfajta megfogalmazására és a rurális településeknek az újrapozicionálására és arra hogy megváltoztassák azon képzeteket, miszerint a vidék fogalma egyenlő az elmaradottsággal. 


\section{TEMATIKUS TANULMÁNYOK - Székelyföld - térség és társadalom}

\section{A TELEPÜLÉSMARKETING ÉS MÁRKÁZÁS SZEREPE A HELYI FEJLESZTÉSI GYAKORLATBAN}

Ezek a változások szorosan kapcsolódnak a helyi márkázás elméletéhez és gyakorlatához. A San Eugenio - Barniol (2015) szerzőpáros azt hangsúlyozza, hogy egymással szorosan összefügg a területi alapú identitásnak az építése, a helyi fejlesztési gyakorlat és a téralapú identitás egészének a promoválása, népszerüsítése (1. ábra). Utalva Gold és Ward (1994), Messely et al. (2010), Zimmerbauer (2011) munkáira megállapítják, hogy ez a fajta megközelítés nagyon megerősíti a vidéki térségek márkázásának (rural branding) gyakorlatát. Ez a három elem összefügg, és ugyanakkor hatnak egymásra. Ez a megközelítés szemlélteti leginkább az általam is képviselt nézetet, amelyet főként tereptapasztalataim során alakítottam ki. Azokon a településeken ahol erős, elkötelezett közösség alakult ki sokkal inkább megfigyelhető, hogy a helyi fejlesztési gyakorlatokban is elől járnak. A jól múködő gyakorlatok általában nagyobb hírverést is kapnak, beszélnek róluk úgy a közösségen belül, mint kívül, ez hozzájárul ismét a közösségépítéshez, erősítéshez.

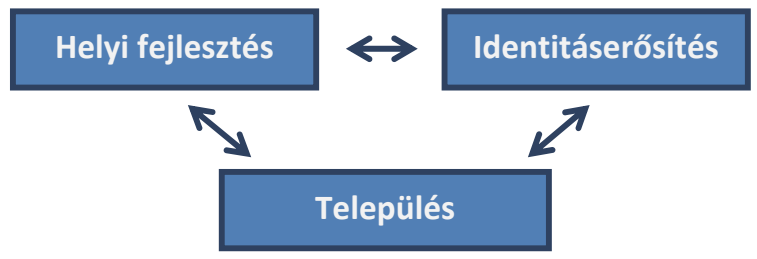

1. ábra: Helyi fejlesztés, identitás és márkázás összefüggései Forrás: San Eugenio - Barniol (2015) alapján saját szerkesztés

A fent említett folyamat része az új vidékfejlesztési paradigmának (new rural development) OECD (2006), amely jelentős mértékben elfordul a központi irányításra alapozó fejlesztési modelltől, és egyre nagyobb hangsúlyt fektet az endogén adottságokra alapozó megközelítésre.

Több szerző is (Vik - Villa 2010, Mettepenningen et al. 2012) kiemeli a helymárkázási kezdeményezések fontosságát a közösség-alapú vidékfejlesztés keretén belül. Véleményük szerint a helymárkázás hatásai erőteljesen érzékelhetőek a helyi közösségek megerősödésében, a helyi identitás konszolidációjában, valamint az endogén tényezők újraértékelésében.

A helyi identitás és márkázási tevékenység szoros kapcsolatban áll egymással, Kavaratzis és Hatch (2013) megközelítésében a márkázás során olyan elemeket kell bevonni és kommunikálni, amelyek meghatározzák egy adott hely identitását, amelyek egyaránt elfogadottak a helyiek és a külső szemlélők által is. Ez a megközelí- 


\section{TEMATIKUS TANULMÁNYOK - Székelyföld - térség és társadalom}

tés túlmegy azon az általános elképzelésen, miszerint a márkázás egy jól kigondolt (szakértők és településvezetők által elfogadott) képet próbál kialakítani a helyről.

A közösség-alapú vidékfejlesztési modell a párbeszédet, a kommunikációt helyezi középpontba a korábbi vezetőségi központú megközelítéshez képest, és ennek megfogalmazott célja összekötni a helyi tervezési folyamatokat a helyek vonzerejének növelésével (Healey 2006, Lysgárd - Cruickshank 2013).

Ntounis (2013), Niedomysl - Jonasson szerzőpárosra hivatkozva, bevezeti az imázs szerepét is. Úgy határozza meg a helymarketinget, mint azok a helyi szereplők által irányított kezdeményezések, amelyek a külső tőke bevonását célozzák azáltal, hogy törekednek a hely imázsának versenyképessé tételére. Az ő megközelítésében a holisztikus marketingfolyamat közvetlenül és közvetve is hozzájárul a települések versenyképességének növeléséhez, a márkaszemélyiség kialakításához, helyi identitáserősítéshez és nem utolsósorban a helyi lakosság életminőségének javításához (Ntounis 2013).

Jellemző azonban, hogy maguk a rurális települések idegenkednek a marketingszemlélettől. Egyrészt azért, mert sok esetben úgy gondolják, hogy „nincs mit eladniuk", nem rendelkeznek olyasvalamivel, amivel a településen kívül élők (turisták, befektetők stb.) érdeklődését igazán fel tudnák kelteni. Ez sok esetben igaz lehet, de csak akkor, ha csupán a település „termékeit” tekintjük értéknek, például a településre jellemző népies tárgyakat, műemlékeket, különleges épületeket, egyedi természeti értékeket, látványosságokat, kiállításokat, eseményeket, és ezeket külső célcsoportoknak akarjuk „eladni”.Másrészt pedig, ha meg is születik az igény az ilyen jellegű tevékenységek iránt, a településmarketing alkalmazásához fontos lenne külön, megfelelő kompetenciával rendelkező munkaerőt bevonni a fejlesztési munkákba, vagy a meglévőt kiképezni, és erre ritkán tudnak elkülöníteni forrásokat.

Ezzel szemben nagyobb települések vezetőségei sokszor szükségesnek látják azt, hogy népszerūsítsék településeiket, foglalkozzanak a külső, belső kommunikációval annak érdekében, hogy növeljék a pozitív megítélést, az ismertséget. A településmárkázás jelentősebb szerepet kap a globalizálódási folyamatok kapcsán (Knox Marston 2001), hisz egyre inkább felértékelődnek a helyek, és sok település arra törekszik, hogy felkerüljön a „térképre”.

Sok rurális szereplő a márkázási tevékenységre úgy tekint, mint ami ellensúlyozni tudja a szociális és gazdaságfejlesztési problémákat. Az olyan társadalmi problémák, mint az elöregedő falvak, fiatalok migrációja, alacsony iskolázottsági szint számos vidéki település számára jelentenek valós problémát (Stockdale 2006), és közvetlenül befolyásolják a települések megítélését. Ezek a szociális problémák sokszor elrejtik a települések valós értékeit, éppen ezért a megfelelő márkázási tevékenység által előtérbe kerülhetnek azok a természeti, kulturális és egyéb értékek, amelyek segíthetnek a települések életképességének javításában. 


\section{TEMATIKUS TANULMÁNYOK - Székelyföld - térség és társadalom}

\section{A CSÍKI-MEDENCE MARKETINGSZEMLÉLETÜ TELEPÜLÉSFEJLESZTÉSÉRE IRÁNYULÓ VIZSGÁLATOK ÉS GYAKORLATOK}

Ha összevetjük a fentiekben bemutatott nagyon lényeges vidékfejlesztési fordulatot mint kihívást, másfelől pedig a vizsgált térség településeinek adottságait és a jelenlegi fejlesztéspolitikai gyakorlatot, akkor hangsúlyozható a pozicionálás, településmarketing, a településimázs és településmárkázás alakításával, helyi identitás erősítésével kapcsolatos szempontok és módszerek vizsgálata, amelyekre ebben a térségben a továbblépéshez nagy szükség van.

Megvizsgálva azonban az eddigi térségi elemzéseket, szakmai anyagokat, megállapítható, hogy ezzel a területtel foglalkozó, komplex, célirányos munkák nem születtek. Viszont megemlíthető néhány olyan kutatás, elemzés, ami részben kapcsolódik ehhez a témához. A székelyföldi turisztikai helymarketing helyzetét kutatta Nagy Benedek (2013). A turisztikai fejlesztési lehetőségek vizsgálata (Horváth 2013) a helyek megjelenítését, illetve a regionális identitástudatnak a térségmarketingben betöltött szerepét is érintette.

Az elkészült fejlesztési stratégiák többsége is a hagyományosabb térségfejlesztési szemléletmódot követi, amelynek elsődleges céljai az infrastrukturális fejlesztések, valamint a gazdaságfejlesztő tevékenységek kialakítása (kiemelten koncentrálva a turizmus és agrárgazdaság fejlesztésére). Ritkábban kerül említésre a marketing szempontú szemléletmód integrálása a fejlesztési tervekbe vagy egyáltalán a térségmarketing eszközeinek az alkalmazása. Ahol pedig megjelentek a marketingstratégiai kezdeményezések, jellemző, hogy ezek pontszerűek, nincsen köztük szinergia.

\section{Kommunikáció és pozicionálás a Csíki-medence településein}

A tanulmányban bemutatott elemzés része egy komplex marketingszempontú, településszintű térséganalízisnek, amely során vizsgáltam azokat a történelmi, társadalmi, gazdasági tényezőket, amelyek meghatározták a Csíki-medence településeinek jelenlegi fejlettségi szintjét és fejlődési pályáját. A terepen szerzett tapasztalatok, valamint az elérhető településspecifikus adatok alapján öt mutatócsoportot alakítottam ki, amelyek - a térségi viszonyokat és a települések jellegét figyelembe véve - alkalmasak lehetnek településanalízis végzésére, ill. kellő szakmai alapot biztosítanak a településtípusok megalkotásához és szem előtt tartják a marketingszempontú megközelítést is (Sikos - Tiner 2008). Ezek a mutatócsoportok a következők voltak: demográfiai mutatók, gazdasági helyzet, fejlesztési lehetőségek, intézmények-szolgáltatások és pozicionálási gyakorlat.

Az öt mutatócsoport egyike volt a pozicionálási gyakorlat, azaz a kommunikációs tevékenység és a kommunikációs csatornák elemzése, ami elengedhetetlen szempont egy település marketingszempontú fejlesztését illetően, ugyanis - mint 


\section{TEMATIKUS TANULMÁNYOK - Székelyföld - térség és társadalom}

ahogyan azt előző kutatások és tereptapasztalatok is bizonyították - befolyásolja az egyes települések fejlődési pályáját.

A lakosság tájékoztatása hat a település általános megítélésére és belső image alakulására. A települések pozicionálását nagymértékben befolyásolják azok a külső és belső események, rendezvények, amelyeket közvetlenül a településhez tudunk kapcsolni.

Ezt az aspektust három változó mentén vizsgáltam: rendezvények, külső kommunikáció és belső kommunikáció. Minden változó esetében öt kategóriát határoztam meg, amelyben az 1-es jelentette a legalacsonyabb, az 5-ös a legmagasabb értéket. Így minden egyes települést a meghatározott változók mentén 1-től 5-ig terjedő értékkel jellemeztem (Székely 2016).

Az elemzéseimet az alábbi 32 településre végeztem el:

$\begin{array}{lll}\text { Csatószeg } & \text { Csíkmindszent } & \text { Csíkszenttamás } \\ \text { Csíkbánkfalva } & \text { Csíkpálfalva } & \text { Gyimesfelsőlok } \\ \text { Csíkborzsova } & \text { Csíkrákos } & \text { Gyimesközéplok } \\ \text { Csíkcsekefalva } & \text { Csíkszentdomokos } & \text { Karcfalva } \\ \text { Csíkcsicsó } & \text { Csíkszentgyörgy } & \text { Kászonaltíz } \\ \text { Csíkcsomortán } & \text { Csíkszentimre } & \text { Kozmás } \\ \text { Csíkdánfalva } & \text { Csíkszentkirály } & \text { Madéfalva } \\ \text { Csíkdelne } & \text { Csíkszentmárton } & \text { Szépvíz } \\ \text { Csíkjenőfalva } & \text { Csíkszentmihály } & \text { Tusnád } \\ \text { Csíkmadaras } & \text { Csíkszentmiklós } & \text { Vacsárcsi } \\ \text { Csíkmenaság } & \text { Csíkszentsimon } & \end{array}$

Az alábbiakban ismertetem a pozicionálási mutatócsoport három változója mentén elvégzett értékelés eredményeit.

\section{a) RENDEZVÉNYEK A CSÍKI-MEDENCÉBEN}

A rendezvények jellege, tartalma és az általuk elért célcsoportok hatást gyakorolnak a települések kialakított képére, arra, hogy milyen imázs alakul ki róluk. Egy-egy sajátos esemény pozicionálási tényezőként is funkcionálhat, ha megfelelő publicitást kap, idővel összekapcsolódik a település nevével. Ez főleg a nagyobb térségi kereteket túllépő rendezvények esetében valósul meg.

A kisebb léptékű, többnyire befelé irányuló, a helyi lakosságot célzó események az identitásépítésben és erősítésben bírnak nagyobb szereppel, hozzájárulnak a belső imázs alakításához.

A változó kategóriáinak meghatározásához azt vettem figyelembe, hogy az egyes településeken milyen gyakorisággal szerveznek eseményeket, és ezeknek milyen a 


\section{TEMATIKUS TANULMÁNYOK - Székelyföld - térség és társadalom}

jellege, irányultsága. A kategóriák kialakításában szakértői véleményeket is segítségül hívtam. Az öt meghatározott kategória: rendezvények hiánya, befelé irányuló kis rendezvények, befelé irányuló rendszeres rendezvények, kifelé és befelé irányuló rendezvények, kifelé és befelé irányuló kiemelkedő rendezvények

A helyi rendezvények szervezése a rendszerváltást követően a legtöbb településen előtérbe került, ezek a folyamatok szoros kapcsolatban vannak a lokális identitás visszaállításával (amelyet a kommunista rezsim 1989 előtt több vonatkozásban megkérdőjelezett vagy pedig felfüggesztett, esetleg kiiktatott), illetve programszerü építésével. A lokális identitás építésnek több fontos eleme is van: magyar településnevek (táblák) használata, helyi intézmények átnevezése, helyi vonatkozású emlékművek, emléktáblák elhelyezése. Ebben a tevékenységsorban jelentős szerepük volt a rendezvényeknek (helyi identitásépítésnek), ezek az aspektusok sokszor össze is kapcsolódtak - pl. Csíkszépvízen a Szent László hagyomány felélesztése, Csíkszentdomokoson a Márton Áron kultusz ápolása és építése. Az események, rendezvények is rákapcsolódnak az identitásépítés egyéb elemeire.

A megyei önkormányzat évente kínál pályázati lehetőséget a helyi rendezvények támogatására - ennek is szerepe van a rendezvények számának szaporodásában. Többnyire azok a települések élnek ezzel a lehetőséggel, ahol az alternatív forrásbevonási gyakorlat is erősebb.

A falunapok előtérbe helyezése a közösség összefogást is erősíti (identitásépítés - a „mi falunk”). Kevés helyen és kisebb helyen jelentek meg olyan törekvések, hogy a rendezvények túllépjenek a lokális kereteken, és turisztikai vagy csak településpozicionálási szempontból kiterjedjenek a térségre vagy még szélesebb körben. A rendezvények száma, gyakorisága, hatóköre nyilvánvalóan összefügg a települések méretével, történelmi hagyományaival, a községközpont státusszal, a helyi elitek közösségi szerepével.

A helyi erőforrások is befolyásolják a rendezvények gyakoriságát, jellegét.

A kategóriák a rendezvények száma, gyakorisága, irányultsága és jelentősége szerint lettek meghatározva. A rendezvények teljes hiánya kevésbé jellemző a térségben, viszont egy-két település esetében nem tapasztalunk semmilyen szerveződést, így egy ilyen kategóriát is szükséges volt kialakítani. A befelé irányuló, kisrendezvények szervezése főleg az olyan települések esetében jellemző, ahol évente pár alkalommal a helyi lakosság számára szerveznek valamilyen eseményt, de ezeknek jelentősége nem túl nagy. A következő kategória a befelé irányuló rendszeresen megszervezésre kerülő rendezvények sora. A települések többsége ide sorolható, ugyanis sok helyen éves rendszerességgel megszervezik az olyan eseményeket, mint a falunapok, szüreti és farsangi bálok, kortárstalálkozók. Ezek a rendezvények azonban fóként a helyi lakosságot szólítják meg, nem törekednek arra, hogy külső érdeklődőket is bevonjanak. A helyi identitás erősítését, a közösségi érzés kialakítását célozzák főként. Már egyfajta igény, „elvárás” is megfogalmazódik a lakosság részé- 


\section{TEMATIKUS TANULMÁNYOK - Székelyföld - térség és társadalom}

ről, hogy minden évben megszervezésre kerüljenek ezek az események. A következő kategória településein a rendszeresen megszervezésre kerülő belső rendezvények mellett külső célcsoportokat is megszólító eseményekre is sor kerül alkalmanként, ezek többsége olyan alkalmi rendezvény, ami főként a közeli települések, esetleg a térség többi lakóját célozzák meg (fúvós találkozók, farsangi rendezvények, színjátszó találkozók, sportesemények, lovas versenyek stb.). Végül pedig néhány település esetében beszélhetünk kifelé és befelé irányuló jelentősebb rendezvényekről (ezek alkotják az ötödik kategóriát). A kifelé irányuló rendezvények már túlmutatnak a közvetlen térségen, és akár a medence vagy a megye egészére is kiterjednek. Ezek olyan események, amelyeknek pozicionáló szerepük is van, hiszen legtöbbjük már hagyományszerűen kerül megszervezésre évente, így összekapcsolható a település nevével (ilyen pl. a csíkszépvízi káposztavágás vagy a madéfalvi hagymafesztivál és a dánfalvi állatvásár is).

A vizsgált települések közül kettő esetében tapasztalhatjuk a rendezvények hiányát. Csíkjenőfalván és Csekefalván még a hagyományosnak tartott településnapokat sem szervezik meg. Az említett települések viszont szervesen kapcsolódnak a közigazgatási központ eseményeihez (Karcfalva és Csíkszentmárton), így általában az ott szervezett eseményeken vesznek részt leginkább.

Befelé irányuló kisrendezvények szervezése elég gyakori a települések többségének életében, azonban néhány esetében ez korlátozódik a településnapokra (falunapokra), amit évente - sokszor inkább szokásból, kényszerből - szerveznek meg. A vizsgált települések közül hat esetében (pl. Tusnád, Csíkpálfalva, Csatószeg, Csíkszentmihály) tapasztalható, hogy a belső rendezvények száma minimális, évente egy-két eseménynél többre nem kerül sor. Ezek a rendezvények pedig főként belső irányultságúak, a helyi lakosság számára szervezik. Visszhangjuk pedig jelentéktelen.

A falvak jelentős részében azonban a falunapokon túl több rendszeresen szervezett, befelé irányuló rendezvényt találunk. A térségben megvannak azok a hagyományos események, ünnepek, amelyek a legtöbb helyen megszervezésre kerülnek. Ilyenek a vallási ünnepek ( búcsúk, szent-napok), nemzeti ünnepek (március 15., október 23.), a bálok (szüreti bál, farsangi bál, hagyományos karácsonyi és húsvéti bálok), hagyományőrző ünnepek (farsangbúcsúztató, húsvéti határkerülés), az egyes szervezetek által megrendezett események (önkéntes tǔzoltó alakulatok versenyei, báljai, ifjúsági szervezetek rendezvényei, fúvós találkozók, színjátszó találkozók) és a kortárstalálkozók is. Ezek olyan rendezvények, amelyek nem föltétlenül a település teljes lakosságát mozgatják meg, hanem sokkal inkább egy-egy csoport számára szervezik. Az egyes találkozók, bálok, sportversenyek ugyan nem csak kifejezetten a helyieket szólítják meg, hanem a környékbelieket is, viszont jellegükből adódóan elég zártnak tekinthetők és inkább belső irányultságúak. Ebbe a kategóriába összesen 14 települést soroltunk. Ezeken a helyeken minden évben megszervezésre ke- 


\section{TEMATIKUS TANULMÁNYOK - Székelyföld - térség és társadalom}

rülnek a fent említett események, azonban visszhangjuk minimális, kevésbé szánják ezeket a külső érdeklődőknek, sokkal inkább identitáserősítő funkciójuk van.

Néhány település esetében, az előzőekben említett rendezvények mellett megszervezésre kerülnek olyan események is, amelyeknek külső irányultságuk is van. A kifelé és befelé irányuló rendezvények kategóriába hat olyan települést soroltunk, ahol az egyes rendezvények „kinőtték” magukat és a szélesebb közönség számára is érdekesekké váltak. Legtöbbjük esetében ez nem volt föltétlenül egy tudatos döntés, sokkal inkább a rendezvények jellege miatt kerültek az érdeklődés központjába. Ilyen rendezvények a csíkszentmiklósi kolbászfesztivál, a dánfalvi és kozmási állatvásárok, a csíkszentmártoni Márton-napi búcsú, a kászoni farsangtemetés (bikaütés).

Kifelé és befelé irányuló jelentős rendezvénye négy településnek van (Csíkszentdomokos, Madéfalva, Csíkszépvíz és Gyimesközéplok). Jellemző ezekre a falvakra, hogy elég aktív a kulturális szervezőerő, ez hatással van a rendezvények számára és jellegére is. Az olyan nagyobb rendezvények, mint a Madéfalvi Hagymafesztivál, Csíkszentdomokosi Lovasnapok, a szépvízi Káposztafesztivál vagy a gyimesközéploki Csángó Túrós Puliszka Fesztivál évről-évre egyre nagyobb népszerűségnek örvendenek, számos vendéget és érdeklődőt vonzva a településekre. Itt már megjelent egyfajta tudatosság az események kommunikációjában. Sokkal nagyobb a viszszhangjuk (akár az országos és magyarországi médiában is beszámolnak ezekről), saját arculattal rendelkeznek, és egyre inkább próbálják alkalmazni a települések pozicionálásában is ezeket a rendezvényeket.

A kategória települései nem csak a külső rendezvények szervezésére fektetik a hangsúlyt, hanem a rendszeres belső rendezvényekre is. A hagyományos térségi események mellett szinte hetente rendeznek valamilyen kisebb előadást, vetélkedőt, vásárt, foglalkozást, különböző táborokat.

Összességében elmondható, hogy a Csíki-medence településein szervezett rendezvények többségének főként közösségépítő, identitáserősítő funkciója van, a kifelé irányuló, kifejezetten „turistacsalogató” rendezvények koncepciója még nagyon kevés helyen született meg. Nem jelentenek prioritást a pozicionálási gyakorlatban sem. 


\section{TEMATIKUS TANULMÁNYOK - Székelyföld - térség és társadalom}

1. táblázat: Települések besorolása rendezvényeik szerint

\begin{tabular}{|l|l|}
\hline \multicolumn{1}{|c|}{ Kategóriák } & \multicolumn{1}{c|}{ Települések } \\
\hline Rendezvények teljes hiánya & Csíkcsekefalva, Csíkjenőfalva \\
\hline $\begin{array}{l}\text { Befelé irányuló } \\
\text { kisrendezvények }\end{array}$ & $\begin{array}{l}\text { Csíkcsomortán, Csíkpálfalva, Csíkdelne, } \\
\text { Csíkszentmihály, Csatószeg, Tusnád }\end{array}$ \\
\hline $\begin{array}{l}\text { Befelé irányuló rendszeres } \\
\text { rendezvények }\end{array}$ & $\begin{array}{l}\text { Vacsárcsi, Csíkborzsova, Csíkmenaság, Karcfalva, } \\
\text { Csíkmindszent, Csíkrákos, Csíkbánkfalva, Kozmás, } \\
\text { Csíkszentgyörgy, Csíkmadaras, Csíkszentsimon, } \\
\text { Csíkcsicsó, Csíkszenttamás, Csíkszentkirály }\end{array}$ \\
\hline $\begin{array}{l}\text { Kifelé és befelé irányuló ren- } \\
\text { dezvények }\end{array}$ & $\begin{array}{l}\text { Csíkszentmiklós, Csíkszentmárton, Csíkszentimre, } \\
\text { Csíkdánfalva, Kászonaltíz, Gyimesfelsőlok }\end{array}$ \\
\hline $\begin{array}{l}\text { Kifelé és befelé irányuló } \\
\text { jelentős rendezvények }\end{array}$ & $\begin{array}{l}\text { Szépvíz, Madéfalva, Gyimesközéplok, } \\
\text { Csíkszentdomokos }\end{array}$ \\
\hline
\end{tabular}

Forrás: saját szerkesztés

\section{b) KÜLSŐ KOMMUNIKÁCIÓS TEVÉKENYSÉG A CSÍKI-MEDENCE TELEPÜLÉSEIN}

A térségi ismertség megteremtésének, az értékek, tevékenységek bemutatásának az egyik legalkalmasabb módja a tudatos, folyamatos kommunikáció. A hatékonyan múködő kommunikációs folyamat számos tényezőre van jelentős hatással. Egyrészt javítja a településképet, hozzájárul ahhoz, hogy szélesebb körben megismerjék az adott települést, ami közvetve hat az idegenforgalom alakulására, másrészt a pozitív településimázs növeli az együttműködések, befektetések és támogatások esélyét is.

A változó kialakításakor figyelembe vettem az alkalmazott online kommunikációs eszközöket, a sajtójelenlétet, valamint a települések bemutatását segítő promóciós anyagok formáját és számát. A felállított öt kategória a következő: kommunikációs gyakorlat hiánya, részleges kommunikációs gyakorlat, mérsékelt kommunikációs gyakorlat, jelentős kommunikációs gyakorlat, kiemelkedő kommunikációs gyakorlat.

A külső kommunikáció, az egyes kommunikációs eszközök, csatornák alkalmazása jelentősen befolyásolja a településekről alkotott képeket, a falvak ismertségét és legfőképp azt, hogy miként sikerül megmutatkozniuk, miként tudják megjeleníteni tevékenységüket, értékeiket, kínálatukat. Az eddigi tapasztalatok azt mutatják, hogy ez egy olyan terület, amivel még nagyon kevesen foglalkoznak tudatosan. Egyre inkább kezd megfogalmazódni az igény rá, viszont sok helyen, éppen a tapasztalatok ill. szakértelem hiányában ez a tevékenység háttérbe szorul, vagy ha igyekeznek is foglalkozni vele, kevésbé rendszeres, megtervezett és nem érzékelhető a hatékony- 


\section{TEMATIKUS TANULMÁNYOK - Székelyföld - térség és társadalom}

sága. Az elemzés során hat olyan szempont került megvizsgálásra, amely tükrözi az egyes települések külső kommunikációjának jellegét és aktivitását. Minden település esetében számba vettem, hogy rendelkeznek-e saját, múködő honlappal, van-e olyan hivatalos közösségi oldal, ami információkat szolgál a településről, megtalálható-e az online térben valamilyen bemutató, ismertető kisfilm az adott településről. Ezen tényezők mellett a sajtómegjelenések, promóciós, ismertető anyagok és a Wikipédia szócikkek is bekerültek a vizsgált szempontok közé. A sajtómonitoring úgy történt, hogy a székelyhon.ro helyi hírportál keresőjében, a település nevekre kiadott találatok száma került feljegyzésre. Mint a többi mutató esetében, itt is öt kategóriát határoztam meg aszerint, hogy milyen kommunikációs eszközöket alkalmaznak az egyes települések. A kommunikációs gyakorlat hiánya jellemzi a települések egy részét, ezeken a helyeken egyáltalán nem foglalkoznak a kifelé irányuló kommunikációval, még saját település-honlapot sem működtetnek, sőt, ha információt szeretnénk keresni ezekről a településekről, csupán hiányos és nagyon alapszintű információkat tartalmazó Wikipédia szócikkeket találunk. Részleges kommunikációs gyakorlata van annak a néhány településnek, amelynek már van valamilyen közösségi oldala vagy kezdetleges honlapja, esetleg néhány hírt is találunk a regionális sajtóban róluk, azonban ezek sok esetben nagyon rendszertelenek, és feltehetőleg nem a település részéről érkezett az információközlés, hanem az újságok megkeresésére. Mérsékelt kommunikáció jellemzi a települések legnagyobb részét, ez azt jelenti, hogy működtetnek weboldalt, meg közösségi profil oldalakat, amelyek többé-kevésbé aktuálisak, viszont technikai szempontból már régen elavultak. Jelentős, illetve kiemelkedő kommunikációval nagyon kevés település esetében találkozunk. Általában valamelyik önkormányzati alkalmazott kapja meg feladatként ennek a tevékenységnek az ellátását, így valamennyire rendszeres a kommunikáció, viszont tartalmilag és formailag sok esetben hiányos. Néhány falu számára készítettek promóciós anyagokat és bemutató kisfilmeket is, viszont tervezett, hosszútávú marketingkommunikációs kampányról sehol nem beszélhetünk.

\section{Hiányos és részleges kommunikációs gyakorlat}

A megvizsgált szempontok szerint (online kommunikáció, lakossági kommunikáció és külső megmutatkozás) összesen nyolc település sorolható ebbe a két kategóriába. Ezek a következők: Csíkdelne, Csatószeg, Csíkmindszent, Csekefalva, Csíkszentmiklós, Kozmás, Tusnád, Gyimesfelsőlok. A felsorolt települések közül az első öt nem közigazgatási központ, ezért feltételezhető, hogy az adott települések kommunikációja az egyes községközpontokra van bízva, amelyek kivétel nélkül mind a harmadik kategóriában kaptak helyet. Amellett, hogy ezek a települések nem önállóan müködnek, az is közös vonásuk, hogy kis települések alacsony lakosságszámmal, így kicsi az igény az önálló bemutatkozásra. Ezeknek a településeknek nincsen önálló 


\section{TEMATIKUS TANULMÁNYOK - Székelyföld - térség és társadalom}

honlapjuk, közösségi oldalt sem működtetnek, csupán néhány, a lakosság által kezdeményezett belső csoportot találunk a Facebook közösségi oldalon. A sajtómegjelenések száma is viszonylag alacsony, jellegükből adódóan pedig feltételezhető, hogy nem a települések kezdeményezésére jöttek létre ezek a sajtóhírek. Amivel mind az öt település rendelkezik, az a Wikipédia bejegyzés, azonban ezek a szócikkek is nagyon általánosak, rövidek. A három községközpont esetében (Kozmás, Tusnád, Gyimesfelsőlok) is az online jelenlét nagyon mérsékelt, hisz Gyimesközéplok egyáltalán nem rendelkezik weboldallal, míg a másik két település honlapja is tartalmilag nagyon szegényes és elavult, hivatalos közösségi oldala egyik településnek sincs. A rendelkezésre álló információk alapján elmondható, hogy a sajtóval való kommunikáció is hiányos, többnyire sporteseményekkel, balesetekkel kapcsolatos hírekben kerülnek említésre a települések nevei, ritkábban néhány helyi eseménnyel, rendezvénynyel hozzák kapcsolatba.

Összességében megállapítható, hogy az ebbe a csoportba tartozó falvak menedzsmentje nem fektet hangsúlyt a kommunikációs tevékenységre, egyáltalán nem tartozik a prioritások közé, ennek következtében a települések bemutatása, nyilvános megjelenítése, a róluk összegyűjthető információk összessége mérsékelt, így a kialakult arculatuk is vagy nagyon hiányos és torz képet nyújt, vagy ismeretlenek maradnak a külvilág számára.

\section{Mérsékelt kommunikációs gyakorlat}

A vizsgált települések többsége ebbe a kategóriába sorolható (21 falu). Ezen települések alkalmazzák az egyes kommunikációs csatornákat, de kevésbé van szó összehangoltságról, integrált kommunikációról és tudatosságról.

Az összes település, amely ebbe a kategóriába került, rendelkezik saját honlappal, azonban fontos megjegyeznünk, hogy a weboldalak tartalma, interaktivitása, aktualitása és design-ja nagyon változó. Találunk néhány olyan korszerű honlapot, amely követi a legújabb irányzatokat - pl. Csíkmadaras, Csíkrákos esetében - de olyat is, amelyet hosszú évek óta nem módosítottak, megtartva egy hagyományosabb, kevésbé felhasználóbarát felületet. Ilyen weboldalakkal rendelkezik pl. Kászonaltíz, Csíkszentmárton vagy éppen Gyimesközéplok.

A honlapok aktualitását vizsgálva megállapítható, hogy a települések többsége igyekszik az éppen aktuális híreket mindig frissíteni, azonban az oldalakon található információk többsége az indítás óta nem lett frissítve, kiegészítve.

Ha a honlapok tartalmát vizsgáljuk, általánosan elmondható, hogy főként település ismertetőket, a lakosoknak szánt fontosabb információkat, a helyi önkormányzat hivatalos dokumentumait és a törvény által előírt információkat találjuk az oldalakon. Turisztikai célzatú tájékoztató anyag kevés van, és nem is jelenik meg mindenhol. 


\section{TEMATIKUS TANULMÁNYOK - Székelyföld - térség és társadalom}

A csoportból érdemes kiemelni néhány olyan települést, amelyek ugyan közigazgatási központokhoz tartoznak, de mégis rendelkeznek saját honlappal, ilyenek pl. Csíkcsomortán, Vacsárcsi, Csíkborzsova és Csíkbánkfalva. Egyik weboldal sem a legkorszerűbb, azonban mindegyiken aktuális híreket tesznek közzé és kifejezetten a faluval kapcsolatos információkat találunk. Ez a tény is jelzi, hogy egyfajta önállósodásra törekednek, és amellett, hogy általában a községi honlapon találunk némi tájékoztatót ezekről a falvakról is, mégis fontosnak tartják, hogy saját online felületet müködtessenek, egyrészt a helyi közösség informálása, de a külvilág irányába való megmutatkozás céljából is.

A csoport települései közül összesen kilenc olyan település van (Csíkcsomortán, Csíkpálfalva, Csíkszentmihály, Csíkrákos, Csíkbánkfalva, Csíkmadaras, Csíkszentsimon, Csíkszenttamás, Kászonaltíz), amelyik rendelkezik hivatalos közösségi oldallal, ezek általában össze vannak kötve a honlapokkal. Jellemzően a Facebook oldalak sokkal aktívabbak, a tartalmak közzététele rendszeresebb és gyakoribb, mint a honlapokon. Több száz, akár ezer követője van ezeknek az oldalaknak. Legfőképp a lakosság körében közkedvelt ez a kommunikációs csatorna. A kászonaltízi és bánkfalvi oldalak esetében nem észlelhető olyan jelentős aktivitás, mint a többi hét oldalon.

Bemutató kisfilmje egyetlen településnek, Csíkszentimrének van. A videómegosztó portálokon találunk ismertető videókat más településekről is, ezek azonban az egyes televízió csatornák (Hargita TV, Erdély TV és Székely TV) adásainak részletei, és nem kifejezetten településnépszerűsítő filmek.

A csoportba sorolt településekről szóló sajtóanyagok viszonylag gyakoriak, a legfontosabb eseményekről, rendezvényekről, illetve fejlesztésekről találunk hírösszefoglalókat, beszámolókat és felhívásokat is. Ugyanakkor a települések sokszor helyi sportesemények kapcsán kerülnek említésre egy-egy cikkben.

Megvizsgálva a csoportba tartozó falvak kommunikációs tevékenységét, összességében elmondható, hogy ezeken a településeken kezdték felismerni a kommunikációs eszközök alkalmazásának fontosságát, próbálnak párhuzamosan több csatornán is szólni a helyi lakossághoz és a környezethez, azonban sokszor hiányosságok észlelhetőek. A kommunikáció többnyire rendszertelen, kevésbé van összehangolva, a tartalmi követelményeknek sem felel meg mindig. Ennek legfóbb oka az, hogy az önkormányzatok nem foglalkoztatnak olyan szakembert, aki tudatosan megszervezné a kommunikációs tevékenységet, vagy legalább az online felületeket megfelelően menedzselné.

A kommunikáció főként a helyi lakosságot célozza, kevésbé fektetnek arra hangsúlyt, hogy a környezet számára is megmutatkozzanak. A jelentősebb ünnepek, események vagy akár a helyi értékek nem kerülnek megfelelő megjelenítésre. 


\section{TEMATIKUS TANULMÁNYOK - Székelyföld - térség és társadalom}

\section{Jelentős és kiemelkedő kommunikációs gyakorlat}

Az elemzett szempontok szerint három település sorolható ezekbe a kategóriákba: Csíkszentdomokos, Madéfalva és Csíkdánfalva. Ezek a települések közigazgatási szempontból is önálló települések, nem tartozik hozzájuk közigazgatásilag más falu, ez könnyítő tényezőnek számít kommunikációs szempontból.

Mindhárom település esetében jellemző, hogy tudatosabban és rendszeresebben adnak hírt magukról, mint a másik két csoportba sorolt falvak. Mindig aktuális információkat találunk a közösségi oldalakon és a honlapokon is. Tartalmilag színesebbek és változatosabbak a bejegyzések, ugyanis az eseményekről szóló tájékoztatások mellett találhatóak fotók, videók, beszámolók is. Több kommunikációs eszközt is alkalmaznak párhuzamosan, többnyire összehangolva. Ugyanakkor az is jellemző, hogy a helyi sajtóban sokkal gyakrabban jelennek meg hírek, beszámolók ezekről a településekről. A kommunikációs csatornákon keresztüli információ közvetítés sokkal tudatosabb és rendszeresebb, de ezeknek a településeknek az esetében is fóként a belső közönség elérése a cél. A kifelé irányuló kommunikáció néhány esemény beszámolójában kimerül és a település megjelenítése, az értékek, a sajátosságok megmutatása továbbra is hiányos.

2. táblázat: Települések besorolása külső kommunikációs gyakorlatuk szerint

\begin{tabular}{|l|l|}
\hline \multicolumn{1}{|c|}{ Települések } & \multicolumn{1}{c|}{ Kategóriák } \\
\hline $\begin{array}{l}\text { Kommunikációs gyakorlat } \\
\text { hiánya }\end{array}$ & $\begin{array}{l}\text { Csíkdelne, Csatószeg, Csíkszentmiklós, } \\
\text { Csíkmindszent, Csíkcsekefalva }\end{array}$ \\
\hline $\begin{array}{l}\text { Részleges kommunikációs } \\
\text { gyakorlat }\end{array}$ & Kozmás, Tusnád, Gyimesfelsőlok \\
\hline $\begin{array}{l}\text { Mérsékelt kommunikációs } \\
\text { gyakorlat }\end{array}$ & $\begin{array}{l}\text { Csíkcsomortán, Vacsárcsi, Csíkpálfalva, } \\
\text { Csíkborzsova, Csíkmenaság, Csíkszentmihály, } \\
\text { Karcfalva, Csíkrákos, Csíkszentmárton, } \\
\text { Csíkbánkfalva, Csíkjenőfalva, Szépvíz, } \\
\text { Csíkszentgyörgy, Csíkszentimre, Csíkmadaras, } \\
\text { Csíkszentsimon, Csíkszentkirály, Csíkcsicsó, } \\
\text { Csíkszenttamás, Kászonaltíz, Gyimesközéplok }\end{array}$ \\
\hline $\begin{array}{l}\text { Jelentős kommunikációs } \\
\text { gyakorlat }\end{array}$ & Csíkdánfalva, Madéfalva, Csíkszentdomokos \\
\hline $\begin{array}{l}\text { Kiemelkedő kommunikációs } \\
\text { gyakorlat }\end{array}$ & - \\
\hline
\end{tabular}

Forrás: saját szerkesztés 


\section{TEMATIKUS TANULMÁNYOK - Székelyföld - térség és társadalom}

\section{c) A CSÍKI-MEDENCE TELEPÜLÉSEINEK}

BELSŐ KOMMUNIKÁCIÓS TEVÉKENYSÉGE

A lakossági kommunikációnak két fontos szempontját kell még megemlíteni, egyrészt a tájékoztatási funkciót, másrészt az identitáserősítő funkciót. A belső kommunikáció rendszeressége, tartalma, formája (közlemények, szóbeli tájékoztatás, lakossági fórumok, helyi újság) meghatározza azt, hogy a helyi lakosság mennyire fogja magáénak érezni a település ügyeit, mennyire lesz jelentős a lakossági aktivitás, részvétel, a településvezetés támogatása. A helyi identitás erőssége a településhez való kötődést, ragaszkodást befolyásolja leginkább.

A mutató meghatározásához a belső kommunikációs eszközöket vizsgáltam (online és hagyományos eszközök). Az öt kialakított kategória a következő: kommunikációs gyakorlat hiánya, részleges kommunikációs gyakorlat, mérsékelt kommunikációs gyakorlat, jelentős kommunikációs gyakorlat, kiemelkedő kommunikációs gyakorlat.

A belső kommunikációs tevékenységnek két olyan fontos szerepe is van, amiért érdemes vizsgálni. Egyrészt a belső kommunikáció rendszeressége, formája utal arra, hogy milyen a lakosság tájékoztatása, másrészt a tartalma, jellege, a használt csatorna azt is megmutatja, hogy van-e identitáserősítő funkciója. A tapasztalat azt mutatja, hogy a térségben összességében inkább a nem formális kommunikációs gyakorlat múködik. A falvakban általában még mindig a személyes kommunikációs csatornák működnek a leginkább, és ezek hatékonyságával a lakosság többnyire meg is van elégedve. Ezek a kommunikációs csatornák településléptékűek, nem községszinten működnek. Éppen ennek köszönhetően a formalizált belső kommunikációra vonatkozó lakossági igények nem erősek (az évi egy hivatalos beszámolóval megelégszik a helyi lakosság).

Jellemző, hogy minden településen évente egyszer (kivételes alkalmakkor kétszer) falugyűlést szerveznek, ahol a vezetőség beszámol tevékenységéről, és a lakosoknak is lehetőségük van kérdezni, megvitatni bizonyos témákat. Ezeknek a fórumoknak a szerepe inkább az, hogy nyilvános teret biztosítsanak a település problémáinak megvitatására. Emellett formalizált kommunikációs módszer a hirdetőtáblák használata, ill. a fogadóórák (ez utóbbiakat a polgármesterek elmondása szerint ritkábban veszik igénybe a lakosok).

Néhány településen helyi újságot is szerkesztenek, ezek általában inkább községi újságok. Megjelenési gyakoriságuk nagyon változó. Van, ahol évente csupán néhány alkalommal jelentetik meg, máshol pedig rendszeresen, havonta. Helyi rádióval is próbálkoznak egy-két helyen, de nincs állandó műsor. Az utóbbi években egyre inkább elterjedtté vált a közösségi oldalak használata, több Facebook csoport is múködik, amelynek kifejezetten a belső tájékoztatás a célja, tagjai a település lakói, és viszonylag erős aktivitás jellemzi. 


\section{TEMATIKUS TANULMÁNYOK - Székelyföld - térség és társadalom}

Kommunikációs gyakorlat teljes hiányáról egy település esetében sem beszélhetünk, hisz mindenhol valamilyen szinten múködik legalább az informális, személyes tájékoztatás. Részleges kommunikáció főleg a nem községközpontok esetében történik, ezekre a helyekre kissé nehezebben, esetleg később jutnak el az információk, mint a központokban. A mérsékelt kommunikáció jellemzi a települések többségét, itt a formális eszközöket is igyekeznek alkalmazni (hirdetőtáblák, falugyűlések, tájékoztató lapok) a személyes kommunikáció mellett. Jelentős és kiemelkedő kommunikációs gyakorlatról tulajdonképpen nem beszélhetünk, viszont van néhány település, ahol a helyi újságnak és a jól működő közösségi oldalaknak köszönhetően a belső hírközlés hatékonyabban történik.

Részleges kommunikációs gyakorlat főleg a kis lakosságszámú településeken jellemző (Csobotfalva, Vacsárcsi, Csíkdelne, Csatószeg, Csekefalva stb.). Itt a személyes kapcsolati hálóknak köszönhetően nagyon gyorsan terjed a hír, tulajdonképpen nincs is szükség formalizált eszközökre.

Mérsékelt kommunikáció jellemzi a térség szinte minden települését. Itt is nagyon erősek a személyes kommunikációs kapcsolatok, de ezek mellett más eszközöket is próbálnak alkalmazni a lakossági tájékoztatásra. Az önkormányzatok elmondása szerint a honlapoknak is ezt a célt kellene szolgálniuk, viszont a tapasztalat azt mutatja, hogy nagyon kevés helyi lakos szokta látogatni a települések honlapjait, sokkal nagyobb sikerük van a közösségi oldalaknak. Azonban ezeknek az a veszélye, hogy legtöbbször személyfüggők, nem az önkormányzattól függ a megosztott tartalom milyensége, gyakorisága, minősége, hanem attól a személytől, aki adminisztrátora az oldalnak.

A jelentős kommunikációs gyakorlattal rendelkező települések kategóriájába soroltam azokat a falvakat, ahol saját újságot, rádiót is működtetnek. Rendszeresen megjelenő lappal csupán néhány település rendelkezik. Karcfalva és Jenőfalva egy községet alkot, így közös újságot szerkesztenek Székaszó néven, Szépvízen szerkesztik a Nádi Suttogót, ami Csíkszentmiklósra és Csíkborzsovába is jár. Csíkcsicsóban a Csíkcsicsó.ma című havilap jelenik meg míg Csíkszentdomokoson a Domokosi Kitekintő. Ugyan a legtöbb helyi lap havilapként van meghatározva, de megjelenésük elég rendszertelen, többnyire két-három havonta adják ki, ez alól kivételt képez a szépvízi újság. 


\section{TEMATIKUS TANULMÁNYOK - Székelyföld - térség és társadalom}

3. táblázat: Települések besorolása belső kommunikációs gyakorlatuk szerint

\begin{tabular}{|l|l|}
\hline \multicolumn{1}{|c|}{ Kategóriák } & \multicolumn{1}{c|}{ Települések } \\
\hline $\begin{array}{l}\text { Kommunikációs gyakorlat } \\
\text { hiánya }\end{array}$ & - \\
\hline $\begin{array}{l}\text { Részleges kommunikációs } \\
\text { gyakorlat }\end{array}$ & $\begin{array}{l}\text { Csíkcsomortán, Vacsárcsi, Csíkpálfalva, } \\
\text { Csíkmenaság, Csíkdelne, Csatószeg, Csíkmindszent, } \\
\text { Csíkcsekefalva, Csíkbánkfalva, Tusnád }\end{array}$ \\
\hline $\begin{array}{l}\text { Mérsékelt kommunikációs } \\
\text { gyakorlat }\end{array}$ & $\begin{array}{l}\text { Csíkborzsova, Csíkszentmihály, Csíkszentmiklós, } \\
\text { Csíkrákos, Csíkszentmárton, Kozmás, Csíkjenőfalva, } \\
\text { Csíkszentgyörgy, Csíkszentimre, Csíkmadaras, Csík- } \\
\text { szentsimon, Csíkszenttamás, Madéfalva, Kászonaltíz, } \\
\text { Gyimesfelsőlok, Gyimesközéplok }\end{array}$ \\
\hline $\begin{array}{l}\text { Jelentős kommunikációs } \\
\text { gyakorlat }\end{array}$ & $\begin{array}{l}\text { Karcfalva, Szépvíz, Csíkdánfalva, Csíkszentkirály, } \\
\text { Csíkcsicsó, Csíkszentdomokos }\end{array}$ \\
\hline $\begin{array}{l}\text { Kiemelkedő kommunikációs } \\
\text { gyakorlat }\end{array}$ & - \\
\hline
\end{tabular}

Forrás: saját szerkesztés

\section{Összegzés}

A települések megfelelő pozicionálása egyrészt versenyelőnyt jelenthet egy-egy település számára, de emellett a márkázási folyamat arra is törekszik, hogy megerősítse a helyi identitást és a településimázst. A márkázási folyamat kiindulópontja a helyi identitásban keresendő, a helyi értékekre, normákra alapozható a márkázási tevékenység és ezáltal erősíthető a helyi identitás is. Ideális esetben a márkázási folyamat során a település azon tényezői kerülnek bemutatásra, amelyekre a hely büszke, és amelyek leginkább tükrözik identitását. A településmarketing feladata lenne minél közelebb hozni az identitást, az imázst és a márkát (azaz a valóságot, valamint a kialakult és kialakítani kívánt képet). Azért, hogy ezek tartalma minél inkább fedje egymást szükséges a hely egyedi sajátosságainak és megkülönböztető előnyeinek folyamatos kommunikációja (Hospers 2004: 274). Ezt egy nagyon fontos megállapításnak tartom, mert lehet a helyeknek bármilyen különleges, egyedi sajátossága, ha arról nem beszélnek, nem ismertetik, nem tudatosítják úgy a külső, mint a belső célcsoportokban nem fog meghatározó tényezővé válni és nem segít a versenyképesség növelésében.

A Csíki-medence településeinek kommunikációs tevékenységének elemzése során beigazolódott az, hogy ebben a térségben is jellemző a marketingkommuniká- 


\section{TEMATIKUS TANULMÁNYOK - Székelyföld - térség és társadalom}

ciós tevékenységektől való idegenkedés. Ennek több oka is van, egyrészt a „nincs amit megjeleníteni”, „nincsenek hírek” szemlélet jellemző. A kommunikáció legfo”képp a rendezvények, események népszerüsítésére terjed ki, a belső kommunikációban a hivatalos információk közlésére fektetik a hangsúlyt, míg a külső kommunikációban is inkább a formális, „kötelező” információk megjelenítésére törekednek (lásd monográfiák, honlapokon szereplő hosszú településleírások). Tudatos, következetes és tervezett kommunikációról szinte egyáltalán nem beszélhetünk, egy település estében sem találkoztam a vizsgálat során olyan elemmel, ami hosszútávon a település tervszerú márkaépítéséhez járulhatna hozzá. Ugyanakkor jelentkezik a szakember- illetve a kompetenciahiány. A településeken nincsenek foglalkoztatva olyan személyek, akiknek kifejezetten a kommunikációs tevékenység lenne a feladatuk, ezt a munkát sok esetben valamelyik önkormányzati alkalmazott vagy vezető végzi. A weboldalak sok esetben megrendelésre készülnek és külső üzemeltetőjük van, ez a rendszer pedig hosszútávon nem múködőképes.

Ha összevetjük a fentiekben bemutatott nagyon lényeges vidékfejlesztési fordulatot mint kihívást, másfelől pedig a vizsgált térség településeinek kiváló adottságait és a jelenlegi fejlesztéspolitikai gyakorlatot, akkor ebből az a következtetés adódik, hogy az erőforrások feltérképezésében, értékek beazonosításában, a települések márkázási, megjelenítési gyakorlatában (külső kommunikáció), a közösségek bevonásában, mozgosításában (belső kommunikáció) illetve az ehhez szükséges képességekben mutatkoznak a legnagyobb hiányosságok. Ez egy olyan komplex helyzetet eredményez, amely csak tervezett, összehangolt tevékenységek sorozatának hatására képes átalakulni, megváltozni. Ezen szemlélet szélesebb körben való érvényesítéséhez szükséges az állandó tematizálás, a kommunikációs tevékenység fontosságának a kiemelése, magyarázata, további ilyen irányú kutatási és elemzési munkák megvalósítása, illetve olyan szakpolitikák és javaslatok kidolgozása, amelyek kifejezetten a rurális települések pozicionálására, illetve újrapozícionálására fektetik a hangsúlyt.

\section{Irodalom}

Agyagási L. (2006): Régió. Fejlesztési törekvések a Székelyföldön. Csíkszereda, Alutus Kiadó.

Almstedt, A. - Brouder, P. - Karlsson, S. - Lundmark, L. (2014): Beyond Post-Productivism: from Rural Policy Discourse to Rural Diversity. Europe Countryside, 4, 297-306.

Ambrus T. (2012): Székely falutízesek. Csíkszereda, Pallas-Akadémia Könyvkiadó.

Beluszky P. (1993): „Tradicionális” területi hátrányok és terápiájuk Magyarországon (1948-1992). In: Kovács K. (szerk.): Település, gazdaság, igazgatás a térben. Pécs, MTA RKK. 49-64. 


\section{TEMATIKUS TANULMÁNYOK - Székelyföld - térség és társadalom}

Biró A. Z. - Laki L. (2001): On he Edge of Globalisation. Central Europen Political Science Review, 5(2) 185-218.

Biró A. Z. - Csomortáni E. - Ozsváth B. H. - Biró Z. Z. - Aczél Zs. (2011): Nemzeti identitás - lokális identitás - versenyképesség. Lokális identitások alakulása a Székelyföldi térségben: helyzetkép és fejlesztési lehetőségek. MTA Határon Túli Magyar Tudományosságért Ösztöndíjprogram. Kutatási jelentés. Kézirat, KAM Regionális és Antropológiai Kutatások Központja.

Biró A. Z. - Gergely O. - Székely K. K. - Ozsváth B. H. - Bogyor I. - Biró Z. Z. (2016): Helyi fejlesztés és innováció a székelyföldi rurális térségben. Domus program. Kutatási jelentés. Kézirat, KAM - Regionális és Antropológiai Kutatások Központja.

Bodó J. (szerk.) (2000): Miénk a tér. Szimbolikus térhasználat a székelyföldi régióban. Helyzetkönyvek. Csíkszereda, Pro-Print Kiadó.

Bodó J. (szerk.) (2011): Szimbolikus térhasználat: ünnepek, jelképek. A Sikeres Székelyföld Szakmai Fórumsorozat kiadványa. Csíkszereda - Sepsiszentgyörgy, Alutus Kiadó.

Demeter Cs. (2014): Rurbanizáció. Területfejlesztési és modernizációs politika székelyföld elmaradott régióiban - 1968-1989. Csíkszereda, Státus Kiadó.

Egyed Á. (2013): A székelyek rövid története a megtelepedéstől 1989-ig. Csíkszereda, Pallas-Akadémia Könyvkiadó.

G. Fekete É. (2008): A fejlődés és versenyképesség értelmezése a kevésbé fejlett térségekben. In: Lengyel I. - Lukovics M. (szerk): Kérdôjelek a régiók gazdasági fejlődésében. Szeged, JATEPress, 130-152.

Hankó V. (1993): Székelyföld. Budapest, Akadémiai Kiadó.

Healey, P. (2006): Collaborative Planning: Shaping Places in Fragmented Societies. Basingstoke, Pelgrave MacMillan.

Horváth A. (2013): Turizmusfejlesztés Székelyföldön - Hargita megyei szemszögből. Nemzeti Kisebbségkutató Intézet, melyi település?

Hospers, G. J. (2004): Place Marketing in Europe. The Branding of the Øresund Region. Intereconomics, 5, 271-279.

Kánya J. (2003): Történeti áttekintés. In: Horváth Gy. (szerk): Székelyföld. BudapestPécs, Dialóg Campus Kiadó.

Kavaratzis, M. - Hatsch, M. (2013): The dynamics of place brands an identity-based approach to place branding theory. Marketing Theory, 13, 69-86.

Knox, P. L. - Marston, S. A. (2001): Places and Regions in Global Context: Human Geography. Upper Saddle River, NJ, Prentice Hall. 


\section{TEMATIKUS TANULMÁNYOK - Székelyföld - térség és társadalom}

Laville, J. L. - Lévesque, B. - Mendell, M. (2005): The Social Economy. Diverse Approaches and Practices in Europe and Canada. In: The Social Economy as a Tool of Social Innovation and Local Development. Background Report. OECD/OCDE et LEED, Párizs, 125-173.

Lysgard, H. K. - Cruickshank, J. (2013) Creating attractive place for whom? A discourse-theoretical approach to knowledge and planning. Environment and Planning 45(12): 2868-2883.

Mettepenningen, E. - Vandermeulen, V. - Van Huylenbroeck, G. - Schuermans, N. Van Hecke, E. - Messely, L. - Dessein, J. - Bourgeois, M. (2012): Exploring synergies between place branding and agricultural landscape management as a rural development practice. Sociologia Ruralis 52(4): 432-452.

Nagy B. (2013): A turisztikai helymarketing Székelyföldön - az imázs- és márkahasználat tudományos megalapozása. Nemzeti Kisebbségkutató Intézet.

Nagy A. J. (2015): A városmarketing és a gazdasági szerkezetváltás összefüggései Manchesterben. Tér és Társadalom 4, 97-115.

Ntounis, N. (2013): The Role of Place Marketing in the Regeneration of Deprived Places. Master of Philosophy, Manchester Metropolian University.

San Eugenio, V. J. - Barniol, C. M. (2015): The Relationship Between Rural Branding and Local Development. A case study in the Catalonia's Countryside: Territoris Serens (El Llucanes). Journal of Rural Studies. 37(2): 108-119.

Sikos T. T. - Tiner T. (2008): Határmentiség és fejlődési térpályák: a regionális együttműködés lehetőségeinek vizsgálata a településmarketing eszközrendszerével a magyar-szlovák határ déli oldalán. Tata, Modern Üzleti Tudományok Fơiskolája.

Stockdale, A. (2006): Migration: per-requisite for rural economic regeneration? In: Journal of Rural Studies, 22(3): 354-366.

Szádeczky K. L. (1993): A székely nemzet története és alkotmánya. Budapest, Akadémiai Kiadó.

Székely K. (2016): A Csíki-medence településeinek típusai és azok marketingszempontú vizsgálata. Gödöllő, Szent István Egyetem.

Vámszer G. (2000): Csík vármegye településtörténete. Csíkszereda, Pallas-Akadémia Könyvkiadó.

Van Der Ploeg, J. - Renting, H. - Brunori, G. - Knickel, K. - Mannion, J. - Marsden, T. Roest, K. - Sevilla-Guzmann, E. - Ventura, F. (2000): Rural Development: From Practices and Policies towards Theory. Sociologia Ruralis, 40(4): 391-408.

Venczel J. (1988): Székely népfelesleg. In: Székely B. (szerk.): Erdély föld - erdélyi társadalom. Válogatott írások. Budapest, Közgazdasági és Jogi Könyvkiadó, 115117. 


\section{TEMATIKUS TANULMÁNYOK - Székelyföld - térség és társadalom}

Vik, J. V. (2010): Books, branding and boundary objects: on the use of image in rural development. Sociologia Ruralis, 50(2): 156-170.

Vitos M. (2002): Csikmegyei Füzetek I. Adatok Csikmegye leírásához és történetéhez. Csíkszereda, Hargita Kiadóhivatal.

Vitos M. (2003): Csikmegyei Füzetek II. Adatok Csikmegye leírásához és történetéhez. Csíkszereda, Hargita Kiadóhivatal.

Woods, M. (2005): Rural Geography. Process, Responses and Experiences in Rural Restructuring. London, Sage Publications.

Woods, M. (2007): Engaging the Global Countryside: Globalizations, Hybridity and the reconstitution of rural place. Progress of Human Geography, 31(4): 485-507. 